\title{
Hubungan Kebiasaan Merokok Dengan Kadar LDL (Low Density Lipoprotein) Pada Pria Usia Produktif di Dusun Tengklik Karangbangun Matesih Kabupaten Karanganyar
}

\author{
Arum Pravitasari, Sulasmi \\ Program Studi Sarjana Terapan Teknologi Laboratorium Medis, Sekolah Tinggi Ilmu Kesehatan Nasional
}

\begin{abstract}
Abstrak
Low Density Lipoprotein (LDL) merupakan jenis lipoprotein yang paling banyak mengangkut kolesterol di dalam tubuh. Kebiasaan merokok merupakan salah satu faktor yang dapat menyebabkan terjadinya peningkatan kadar kolesterol LDL, dimana nikotin yang merupakan salah satu unsur pada rokok merangsang sekresi katekolamin, meningkatkan lipolisis, dan meningkatkan asam lemak bebas. Kadar kolesterol LDL yang berlebihan dalam darah akan meningkatkan risiko penumpukan kolesterol pada dinding pembuluh darah arteri yang diikuti dengan terjadinya aterosklerosis. Tujuan penelitian ini untuk mengetahui hubungan kebiasaan merokok terhadap kadar LDL pada pria usia produktif berdasarkan jumlah konsumsi rokok perhari. Jenis penelitian analitik observasional dengan pendekatan Cross sectional. Metode pemeriksaan enzimatik untuk menganalisis kadar LDL. Populasi dalam penelitian ini seluruh pria usia produktif di dusun Tengklik Karangbangun Matesih Karanganyar, dengan sampel sebanyak 32 orang. Data dianalisa dengan uji Kruskal Wallis. Hasil penelitian menunjukkan jumlah perokok ringan $25 \%$ (12 orang) dan sedang $75 \%$ (20 orang), serta tidak ada perokok berat. Diperoleh nilai p value sebesar 0,000, yang berarti ada hubungan antara kebiasaan merokok dengan kadar LDL pada pria usia produktif.
\end{abstract}

Kata Kunci : Low Density Lipoprotein (LDL), Kebiasaan merokok, Perokok.

\section{Relationship of Smoking Habits With LDL (Low Density Lipoprotein) Levels in Productive Age Men in Tengklik Karangbangun Hamlet Matesih Regency of Karanganyar}

\begin{abstract}
Low Density Lipoprotein (LDL) is the type of lipoprotein that carries the most cholesterol in the body. Smoking habits are one of the factors that can cause an increase in LDL cholesterol levels, where nicotine which is one of the elements in cigarettes stimulates catecholamine secretion, increases lipolysis, and increases free fatty acids. Excessive levels of LDL cholesterol in the blood will increase the risk of cholesterol buildup on the walls of the arteries, followed by atherosclerosis. The purpose of this study was to determine the relationship between smoking habits and LDL levels, and to determine LDL levels in men of productive age based on the number of cigarettes consumed per day. This research is an observational analytic study with a cross sectional approach and uses an enzymatic examination method for LDL levels. The population in this study were men of reproductive age in Tengklik Karangbangun, Matesih Karanganyar hamlet. The sample in this study amounted to 32 samples that matched the inclusion and exclusion criteria who were willing to become respondents. The data were analyzed using the Kruskal Wallis test through the SPSS version 23 program. The results of the research analyzed obtained a $\mathrm{p}$ value of (0.000).LDL levels can be influenced by several factors, including pre-analytic factors ranging from blood sampling, correct labeling and fasting. Analytical factors that influence are related to the quality of the reagents used, calibration of tools, control of tools and reagents, and inspection methods. Postanalytic factors include, calculations, measurements, and reporting are in accordance with the existing Standard Operating Procedures.Based on the results of statistical tests, it can be concluded that there is a relationship between smoking habits and LDL levels in men of productive age in Tengklik Karangbangun Matesih Hamlet, Karanganyar Regency.
\end{abstract}

Keywords: : Low Density Lipoprotein (LDL), Smoking habits, Smokers, Men

Korespondensi : Sulasmi, Program Studi Sarjana Terapan Teknologi Laboratorium Medis Sekolah Tinggi Ilmu Kesehatan Nasional Surakarta, Jalan Raya Solo-Baki Kwarasan Grogol Sukoharjo Jawa Tengah, mobile 081226873220,e-mail sulasmi@stikesnas.ac.id 


\section{Pendahuluan}

Rokok adalah hasil olahan tembakau yang dibuat dan dibungkus serta dihasilkan dari tanaman Nicotiana tobacum. Menurut Adeatma (2014) merokok didefinisikan sebagai suatu perilaku dengan menghisap rokok. Sedangkan dalam Kamus Besar Bahasa Indonesia (KBBI) kata "Kebiasaan" merujuk kepada sesuatu yang biasa dikerjakan dalam hal ini adalah seorang perokok. Selain itu, Adiputra (2013) mendefinisikan kebiasaan merokok dengan kriteria dimana usia seseorang mulai merokok dengan jenis dan jumlah rokok perhari. Aktivitas merokok diukur berdasarkan intensitas dari banyaknya mengkonsumsi rokok.

Berdasarkan jumlah rokok yang dihisap setiap hari, perokok dapat dibedakan menjadi 3, yaitu seseorang perokok ringan yang mengkonsumsi rokok $1-10$ batang per hari, perokok sedang 11 - 20 batang per hari dan perokok berat lebih dari 20 batang per hari (WHO, 2011). Meningkatnya jumlah perokok berisiko terhadap adanya beberapa penyakit seperti kanker (terutama kanker paru-paru), penyakit jantung koroner, infark serebri, emfisema, dan beberapa penyakit akut serta kronis lainnya (Sutrisna B, 2009 dalam Raditya A, 2018).

Penyebab penyakit jantung terjadi karena adanya penyumbatan arteri koroner setelah pecahnya plak aterosklerosis, yaitu tumpukan asam lemak dan sel darah putih pada dinding arteri koroner yang memasok darah ke jantung. Plak yang pecah menciptakan gumpalangumpalan bekuan darah, jika bekuan darah ini cukup besar maka dapat menutup seluruh arteri yang mengakibatkan serangan jantung (Balamba, dkk. 2017). Beberapa penyebab disfungsi endothel dalam proses aterosklerosis, antara lain karena adanya peningkatan kadar LDL termodifikasi, dan adanyaradikal bebas yang disebabkan oleh rokok (Lintong, 2009).

$$
\text { Low Density Lipoprotein (LDL) }
$$
merupakan $60-70 \%$ bagian dari total serum kolesterol. Low Density Lipoprotein mengandung satu lipoprotein yaitu Apo B - 100 (Apo - B), LDL ini merupakan lipoprotein yang paling anterogenik dan merupakan target utama dalam terapi dislipedemia (Soegiarto, 2015).

Salah satu zat yang terkandung di dalam rokok adalah nikotin. Nikotin dipercaya berkontribusi terhadap abnormalitas profil lipid. Efek nikotin, hampir secara keseluruhan dapat melepaskan katekolamin, meningkatkan lipolisis, dan meningkatkan asam lemak bebas (Sanhia, dkk. 2015). Dengan meningkatnya asam lemak bebas membuat produksi kolesterol LDLmenjadi berlebih, sehingga kadarnya dalam darah meningkat (Hamsa, 2014). Zat-zat kimia yang terkandung dalam rokok dapat meningkatkan kadar LDL serta menurunkan kadar HDL (High Density Lipoprotein ). Kadar HDL yang rendah banyak ditemukan pada orang-orang yang merokok sehingga pembentukan kolesterol baik atau HDL yang bertugas membawa lemak dari jaringan ke hati menjadi terganggu. Sementara kebalikannya justru terjadi pada kadar LDL yang tinggi, yang berarti lemak dari hati justru dibawa kembali ke jaringan tubuh dan dapat menyebabkan penyempitan pada pembuluh darah koroner sehingga dapat menimbulkan penyakit jantung koroner (Nisa dkk, 2018).

Peningkatan kadar LDL pada perokok sangat tergantung dari jumlah rokok yang dihisap dan lamanya seseorang merokok. Semakin tinggi kadar LDL di dalam darah akan memberikan risiko yang semakin tinggi pada tubuh (Graha, 2010). Peningkatan kadar LDL di dalam darah dapat dipengaruhi oleh beberapa faktor antara lain: genetik, usia, jenis kelamin, obesitas, aktifitas fisik, pola hidup, konsumsi obat - obatan dan merokok (Kaparang, 2013).

Penelitian yang dilakukan Sanhia, dkk (2015) pada masyarakat perokok di pesisir pantai disimpulkan bahwa terdapat peningkatan kadar kolesterol LDL. Penelitian Juliani, dkk. (2017) pada remaja perokok dan bukan perokok mendapatkan hasil bahwa pada remaja perokok memiliki kadar LDL yang meningkat dengan hasil pada 21 orang responden remaja perokok dengan kategori mendekati optimal (100$129 \mathrm{mg} / \mathrm{dL})$ sebanyak 9 orang $(42,8 \%)$ dan 12 orang $(57,3 \%)$ dengan kategori mengkhawatirkan (130-159mg/dL) dibandingkan dengan kadar LDL pada remaja bukan perokok.

Penduduk dusun Tengklik Karangbangun Matesih Kabupaten Karanganyar mayoritas sebagaipetani. Petani seringkali merokok di waktu senggang atau saat sedang beristirahat. Kebiasaan merokok pada petanidapat memungkinkan adanya kenaikan kadar LDL. Masyarakat yang berusia diantara 15 hingga 64 tahun masih merupakan masa-masa produktif di kehidupannya. Tanggung jawab secara fisik, biologis, ekonomi dan sosial sangat dibutuhkan dan berkaitan erat dengan status kesehatannya saat ini. Banyak penyakit degeneratif yang onsetnya dimulai sejak usia pertengahan menyebabkan produktivitas masyarakat menurun dan masa lansia di kemudian hari menjadi kurang berkualitas. (Masyeni, 2018). 
Tujuan penelitian ini untuk mengetahui hubungan kebiasaan merokok pada pria usia produktif dengan kadar LDL di Dusun Tengklik Karangbangun Matesih Kabupaten Karanganyar.

\section{Metode}

Jenis penelitian ini adalah analitic observational dengan pendekatan cross sectional. Subjek penelitian ini adalah pria dengan kebiasaan merokok. Penelitian dilakukan pada bulan Juli 2021. Populasi nya adalah seluruh pria yang merokok di dusun Tengklik Karangbangun Matesih Kabupaten Karanganyar, dan sampelnya sebanyak 32 orang yang memenuhi kriteria inklusi dan eksklusi. Penjaringan responden menggunakan kuisoner yang disebar di Dusun Tengklik Karangbangun Matesih untuk mendapatkan sampel dan untuk mengetahui kebiasaan merokok. Pemeriksaan kadar LDL dilakukan di Laboratorium Klinik Pratama Sarwo Medika Karanganyar. Alat yang digunakan dalam penelitian ini terdiri dari Spuit, sentrifuge, mikropipet, tabung reaksi, rak tabung, kapas alkohol, torniquet, vacutainer bertutup merah, plester, Metrolab 1600 DRdan reagen LDLUntuk pemeriksaan LDL digunakan darah vena dari subjek penelitian Prosedurpenelitian yang dilakukan adalah (1) Pengambilan spesimendilakukan dengan cara mengambil darah vena pada responden yang telah memenuhi kriteria eksklusi dan inklusi kemudian diperiksa darah lengkap menggunakan alatmetrolab 1600 DR.(2) Pemeriksaan kadar LDL dengan alat metrolab 1600 DR. Pastikan alat metrolab 1600 DR siap. Kemudian pipet reagen 1 sebanyak $450 \mu 1$, reagen 2 sebanyak $150 \mu$ l, dan spesimen sebanyak 7,5 $\mu \mathrm{l}$, kemudian homogenkan dan inkubasi selama 10 menit pada suhu kamar atau 5 menit pada suhu $37^{\circ} \mathrm{C}$, baca absorbansi pada panjang gelombang $450 \mathrm{~nm}$ terhadap raegen blanko, kemudian baca hasil.

Penelitian ini telah mendapatkan persetujuan dari Komisi Etik Penelitian Kesehatan (KEPK) Fakultas Kedokteran Universitas Muhammadiyah Surakarta No.3679/B.2/KEPK-FKUMS/VIII/2021.

\section{Hasil}

Berdasarkan data kuisioner penelitian yang telah disebar di Dusun Tengklik Desa Karangbangun Matesih Kabupaten Karanganyar didapatkan pria dengan usia antara
15 - 64 tahun berjumlah 75 orang,dan didapatkan jumlah pria perokok 46 orang, yang bersedia menjadi responden penelitian sebanyak 32 yang mana 14 orang tidak setuju menjadi responden penelitian.

Tabel 1. Prosentase kebiasaan merokok pria usia produktif

\begin{tabular}{lcc}
\hline $\begin{array}{c}\text { Kebiasaan } \\
\text { Merokok }\end{array}$ & Jumlah (32) & $\begin{array}{c}\text { Prosentase } \\
(\boldsymbol{\%})\end{array}$ \\
\hline Ringan & 12 & 25 \\
\hline Sedang & 20 & 75 \\
\hline Berat & 0 & 0 \\
\hline \multicolumn{1}{c}{ Total } & 32 & 100 \\
\hline
\end{tabular}

Tabel 1 distribusi frekuensi berdasarkan kebiasaan merokok didapatkan 12 (25\%) perokok ringan, 20 (75\%) perokok sedang, dan tidak ada perokok berat $(0 \%)$.

Tabel 2. Distribusi frekuensikadar LDL berdasarkan Kebiasaan merokok

\begin{tabular}{lccccc}
\hline $\begin{array}{c}\text { Kebiasaan } \\
\text { Merokok }\end{array}$ & $\mathbf{N}$ & $\begin{array}{c}\text { Min } \\
(\mathbf{m g} / \mathbf{d L})\end{array}$ & $\begin{array}{c}\text { Max } \\
(\mathbf{m g} / \mathbf{d L})\end{array}$ & $\begin{array}{c}\text { Mean } \\
(\mathbf{m g} / \mathbf{d L})\end{array}$ & $\begin{array}{c}\text { SD } \\
(\mathbf{m g} / \mathbf{d L})\end{array}$ \\
\hline Ringan & 12 & 63 & 91 & 79,17 & 9,024 \\
\hline Sedang & 20 & 101 & 139 & 110,85 & 9,975 \\
\hline Berat & 0 & 0 & 0 & 0 & 0 \\
\hline Total & 32 & & & & \\
\hline
\end{tabular}

Dari tabel 2 subyek penelitian didapatkan dari 32 responden didapatkan didapatkan hasil Kadar LDL pada 12 pria perokok dengan kebiasaan ringan berkisar antara 63 dan 91 $\mathrm{mg} / \mathrm{dL}$ dengan rata-rata sebesar $79,17 \mathrm{mg} / \mathrm{dL}$ dan standar deviasi sebesar 9,024 mg/dL. Kadar LDL pada 20 pria perokok dengan kebiasaan sedang berkisar antara 101 sampai $139 \mathrm{mg} / \mathrm{dL}$ dengan nilai rata-rata sebesar $110,85 \mathrm{mg} / \mathrm{dL}$ dan standar deviasi sebesar $9,975 \mathrm{mg} / \mathrm{dL}$. Pada perokok berat tidak didapatkan hasil atau tidak ada responden yang merokok > 20 batang perhari. Berdasarkan hasil tersebut menunjukkan bahwa mean kebiasaan merokok lebih besar dari simpangan baku sehingga dapat diartikan bahwa datajika nilai standar deviasinya lebih kecil dari nilai mean maka menunjukkan bahwa nilai mean dapat digunakan sebagai representasi dari keseluruhan data. 
Tabel 3. Uji normalitas hubungan Kebiasaan merokok dengan kadar LDL

\begin{tabular}{cccc}
\hline & $\begin{array}{c}\text { Kebiasaan } \\
\text { merokok }\end{array}$ & \multicolumn{2}{c}{ Shapiro-Wilk } \\
Statistic & P value \\
\hline \multirow{2}{*}{ LDL } & Ringan & 0,817 & 0,084 \\
& Sedang & 0,863 & 0,063 \\
\hline
\end{tabular}

Dari tabel 3 uji normalitas dengan Shapiro-Wilk ini didapatkan hasil Kadar LDL pada pria dengan kebiasaan merokok ringan diperoleh nilai statistik sebesar 0,900 dengan nilai $\mathrm{p}$ sebesar 0,160 . Nilai $\mathrm{p}>$ 0,05menunjukkan bahwa data kadar LDL pada pria dengan kebiasaan merokok ringan berdistribusi normal. sedangkan pada data kadar LDL pada pria dengan kebiasaan merokok sedang diperoleh nilai statistik sebesar 0,742 dengan nilai $\mathrm{p}$ sebesar 0,000 . Nilai $\mathrm{p}<$ 0,05 ,menunjukkan bahwa data kadar LDL pada pria dengan kebiasaan merokok sedang berdistribusi tidak normal.Oleh sebab itu dilakukan uji analisis non parametrik. Uji alternatif yang digunakan untuk analisa ini adalah dengan uji Mann Whitney.

Data yang diperoleh dari 32 responden selanjutnya dianalisa menggunakan uji Mann Whitney. Dari analisis uji Mann Whitney didapatkan data sebagai berikut:

Tabel 4. Uji Analisis Hubungan Antara Kebiasaan merokok dengan kadar LDL Low Density Lipoprotein)

\begin{tabular}{cc}
\hline Kadar LDL & P value \\
\hline Kebiasaan merokok & 0,000 \\
\hline
\end{tabular}

Berdasarkan tabel 4. uji analisis Mann Whitneydiketahui nilai $\mathrm{p}=0,000(\mathrm{p}<0,05)$, maka Ho ditolak dan $\mathrm{Ha}$ diterima yang berarti terdapat hubungan antara kebiasaan merokok dengan kadar LDL (Low Density Lipoprotein).

\section{Pembahasan}

Peningkatan kadar kolesterol LDL darah pada usia produktif dapat terjadi karena berbagai faktor, diantaranya adalah genetik, usia, penyakit tertentu, gaya hidup seperti kurangnya aktivitas fisik dan konsumsi makanan yang tinggi lemak atau karbohidrat, dan kebiasaan merokok. Diet tinggi lemak maupun karbohidrat dapat meningkatkan kemungkinan terjadinya obesitas hingga peningkatan kadar kolesterol LDL darah (Sargowo dkk, 2011). Dan jumlah rokok yang dihisap setiap hari berbanding lurus dengan peningkatan kadar kolesterol LDL serum. Peningkatan jumlah rokok yang dihisap setiap hari menyebabkan peningkatan kadar nikotin dan radikal bebas yang terserap oleh tubuh, sehingga dapat memperburuk profil lipid serum pada perokok (Gamit K.S,2013).

Sampel yang didapatkan pada penelitian ini yaitu pria dengan usia produktif 15-64 tahun 75 orang dimana yang bersedia menjadi responden penelitian dan yang memenuhi kriteria inklusi dan eksklusi adalah 32 responden. Pada (tabel 1) didapatkan hasil yang mengkonsumsi rokok 1-10 batang perhari (ringan) 25\%, 11-20 batang perhari (sedang) $75 \%$ dan > 20 batang perhari (berat) $0 \%$. Peningkatan kadar LDL pada perokok sangat tergantung dari jumlah rokok yang dihisap semakin tinggi kadar LDL di dalam darah akan memberikan risiko yang semakin tinggi pada tubuh (Graha, 2010). Menurut penelitian yang dilakukan oleh Gamit K.S, (2013)menemukan bahwa terdapat peningkatan kadar LDL pada perokok. dengan peningkatan nilai yang signifikan pada perokok berat ringan hingga sedang dibandingkan dengan bukan perokok.

Pada (Tabel 3) hasil uji Normalitas menggunakan Saphiro-Wilk didapatkan hasil bahwa kadar LDL pada pria dengan kebiasaan merokok sedang adalah berdistribusi tidak normal. Berhubung kedua distribusi tersebut berbeda, maka diputuskan data tidak berdistribusi normal. Dari hasil perhitungan uji normalitas diperoleh bahwa data tidak berdistribusi normal, maka uji perbedaan kadar LDL pada pada pria dengan kebiasaan merokok ringan dan sedang menggunakan uji Non Parametrik yaitu uji Mann-Whitney.

Berdasarkan hasil uji Mann Whitney diperoleh nilai $\mathrm{p}$ sebesar 0,000. Dengan menggunakan taraf signifikan sebesar 0,05, nilai $\mathrm{p}<0,05$, sehingga terdapat perbedaan kadar LDL yang signifikan pada pria dengan kebiasaan merokok ringan dan sedang. bahwa perbedaan kadar LDL pada pada pria dengan kebiasaan merokok ringan dan sedang adalah bermakna. Hal ini menunjukkan bahwa secara statistik rerata kadar LDL pada pria dengan kebiasaan merokok sedang lebih tinggi dari rerata kadar LDL pada pria dengan kebiasaan merokok ringan. Oleh karena itu kebiasaan merokok berhubungan dengan kadar LDL.

Menurut peneliti peningkatan kadar kolesterol LDL dapat dipengaruhi oleh lamanya dan banyaknya rokok yang dikonsumsi setiap harinya, dimana semakin banyak batang rokok yang dikonsumsi perhari semakin meningkat kadar LDL hal ini bisa terjadi karena pada 
orang yang merokok, zat-zat dalam rokok seperti nikotin dipercaya memberikan kontribusi pada abnormalitas profil lipid. Efek nikotin hampir keseluruhan melepaskan katekolamin, meningkatkan lipolisis dan meningkatkan asam lemak bebas, dengan meningkatnya asam lemak bebas membuat produksi kolesterol LDL yang berlebihan, sehingga kadar LDL meningkat (Juliani, dkk. 2017). Pelepasan katekolamin ini akan mengaktivasi adenil siklase pada jaringan adiposa peningkatan kadar hormon pertumbuhan dan katekolamin menyebabkan peningkatan pelepasan insulin dalam darah,sehingga aktivitas lipoprotein lipase (LPL) akan menurun. Hal ini menyebabkan perubahan profil lipid serum diantaranya meningkatkan kadar kolesterol total, Very Low Density Lipoprotein (VLDL), LDL, trigliserida dan menurunkan kadar HDL (Hamsa, 2014). Hasil penelitian ini sejalan dengan dengan penelitian yang dilakukan oleh Kaparang dkk (2013) yang menunjukkan bahwa pada orang yang merokok didapatkan kadar kolesterol LDL yang meningkat.

Low Density Lipoprotein (LDL) mempunyai komposisi kolesterol paling tinggi dibanding dengan lipoprotein lainnya yaitu sebesar $43 \%$. Meningginya kadar LDL berbanding lurus dengan risiko terkena Penyakit Jantung Koroner (Ujiani,2014). Kadar LDL yang meningkat menyebabkan penyakit Jantung Koroner (PJK) yang merupakan penyakit yang terjadi karena penyempitan sampai penyumbatan arteri (pembuluh nadi) pembuluh darah yang menyediakan darah dan oksigen ke jantung. Selain menyebabkan kenaikan kadar LDL yang dapat memicu terjadi PJK, kebiasaan merokok dapat meningkatkan risiko timbulnya berbagai penyakit seperti gangguan pembuluh darah, kanker paru-paru, kanker rongga mulut, kanker laring, bronchitis, tekanan darah tinggi, impotensi dan gangguan pada kehamilan (Irawati dkk, 2011).

Pada pemeriksaan kadar LDL (Low Density Lipoprotein) hasil dapat dipengaruhi dari faktor pra analitik, analitik, dan post analitik. Pada faktor pra analitik pengambilan darah, pelabelan, puasa yang lebih dari 12 jam. Faktor analitik yaitu kualitas reagen, kalibrasi alat, kontrol alat dan reagen, dan metode pemeriksaan. Sedangkan faktor post analitik meliputi, perhitungan, pengukuran, dan pelaporan sudah sesuai dengan SOP yang ada. Pada penelitian ini pemeriksaan kadar LDL (Low Density Lipoprotein) dilakukan dengan menggunakan alat METROLAB 1600 DR.
Hasil penelitian ini menunjukkan bahwa pada pria perokok yang dikategorikan ringan sedang, dan berat dimana pada kategori sedang memiliki kadar LDL yang meningkat. Penelitian ini sejalan dengan penelitian yang dilakukan oleh Sahnia, dkk (2015), dimana orang yang mengonsumsi rokok kadar LDL-nya mengalami peningkatan. Dan sejalan dengan penelitian Juliani, dkk. (2017) dengan judul Gambaran Kadar Low Density Lipoprotein (LDL) pada Remaja Perokok dan bukan Perokok di Dusun Buyan Desa Pancasari, Kecamatan Sukasada, Buleleng, Bali. Didapatkan hasil, bahwa pada remaja perokok memiliki kadar LDL yang meningkat dengan hasil pada 21 orang responden remaja perokok dengan kategori mendekati optimal (100$129 \mathrm{mg} / \mathrm{dL})$ sebanyak 9 orang $(42,8 \%)$ dan 12 orang $(57,3 \%)$ dengan kategori mengkhawatirkan (130-159mg/dL) dibandingkan dengan kadar LDL pada remaja bukan perokok.

Kelemahan dalam penelitian ini masih terdapat faktor perancu lain yang tidak dapat dikendalikan oleh peneliti, misalnya faktor kebiasaan berolahraga dan konsumsi makanan oleh responden.

Berdasarkan hasil penelitian yang telah dilakukan dapat disimpulkan bahwa terdapat hubungan antara kebiasaan merokok dengan kadar LDL pada pria di Dusun Tengklik Karangbangunm Matesih Kabupaten Karanganyar.

Saran yang dapat disampaikan kepada masyarakat untuk menerapkan pola hidup sehat dengan mengurangi kebiasaan merokok.

\section{Daftar Pustaka}

Adeatma, N. W. 2014. Uji Efektivitas Protein Biji Melinjo (Gnetum gnemon L.) Terhidrolisis Sebagai Hepatoprotektor Terhadap Radikal Bebas Dalam Mencegah Peningkatan Kadar SGOT dan SGPT Tikus Wistar Yang Diinduksi $\mathrm{CCL}_{4}$. Skripsi. Universitas Jember. Jember.

Adiputra, K, A, A. 2013. Gambaran Kebiasaan Merokok Masyarakat di Wilayah Kerja Puskesmas Pekutaan I Kabupaten Jembrana. Jurnal ISM Fakultas Kedokteran Udayana.

Balamba.,M.K, dkk. 2017. Animasi 3 Dimensi Penyakit Jantung Koroner Pada Manusia. E-Journal Teknik Informatika Vol 11, 
No. 1 (2017)Tekno. Informatika Universitas Sam Ratulangi

Gamit K.S., Navanati M.G., Gohel P.M., Gonsai R.N. Effects of Smoking on Lipid Profile. Int $J$ Cur Res Rev. 2013;5(17):36-42

Graha, 2010, 100 Questions \& Answers Kolesterol, Jakarta. PT.Elek Media Komputindo

Hamsa ,Cariappa, Sathisha,. Research and Reviews : Journal of Medical and Health Sciences Sequels of Smoking on Blood Lipid Levels in a Rural Population of South India . J Med Heal Sci. 2014;3(2):50-2.

Irawati, L., Julizar dan Miftah I., 2011. Hubungan jumlah dan lamanya merokok dengan viskositas darah. Majalah Kedokteran Andalas. 35(2), pp: 137-146

Juliani, dkk, 2017.Gambaran Kadar Low Density Lipoprotein (LDL) pada Remaja Perokok dan bukan Perokok di Dusun Buyan, Desa Pancasari, Sukasada, Buleleng, Bali.Chemistry Juli Vol. 4 No 1.

Kaparang P., Sunny W dan Marie K., 2013.Perbandingan kadar Low Density Lipoprotein Cholesterol (LDL-C) pada perokok dan bukan perokok. Jurnal eBiomedik. 1(1),pp: 550-554.

Lintong, P, M. Perkembangan Konsep Patogenesis Aterosklerosis. Jurnal Biomedik, Volume 1, Nomor 1, Maret 2009, hlm, $12-22$.

Masyeni, 2018. Remathoid Atritis. Fakultas Kedokteran Universitas Udayana

Nisa Hainun, Dita Ellyana Artha, Risma. Jurnal Media Laboran, Volume 8, Nomer 1, Mei 2018.

Sahnia, AM., Damajanty HCP. dan Joice NAE., 2015. Gambaran kadar kolesterol Low Density Lipoprotein (LDL) pada masyarakat perokok di pesisir pantai. Jurnal eBiomedik. 3(1), pp: 460-465.
Sargowo D, Andarini S. Pengaruh komposisi asupan makan terhadap komponen sindrom metabolik pada remaja. Jurnal Kardiologi Indonesia. 2011;32:14-23.

Soegiarto, dkk. 2015, Buku Ajar Ilmu Penyakit Dalam, Surabaya. Airlangga University Press (AUP)

Sutrisna B, Surtidewi L, Jusuf A, Hudoyo A, Kusmana D, Setianto B, et al. Estimating The Annual Cost of Smoking-Related Diseases in Indonesia. MEDIA Med Indones. 2009 ; 43 (18) : 247 - 53. Dalam Raditya adi, dkk. Gambaran kadar kolesterol Low Density Lipoprotein (LDL) pada perokok aktif. Meditory. ISSN Online: $2549-1520$, ISSN Cetak: 2338 - 1159, Vol. 6, No. 2. Desember 2018

Ujiani sri, Gambaran Kadar Low Density Lipoprotein (LDL) Cholesterol dan Creatinin Kinase-Myocardial Band (CKMB), Jurnal Analis Kesehatan : Volume 3, nomer 1, Maret 2014

WHO. Cardio Vascular Disease. 2011. Available from :http://www.who.int/mediacentre/factshe ets/fs317/en/index.html Access on : 22 September 2013. 